\title{
Article
}

\section{Analysis on sustainability reporting and earnings management practices. Evidence from an emerging economy}

\author{
Elena Nechita ${ }^{1 *}$
}

1 Department of Accounting and Auditing, Faculty of Accounting and Management Information Systems, Bucharest University of Economic Studies, Piața Romană 6, 1st District, 010374 Bucharest, Romania * Correspondence: elena.nechita@cig.ase.ro;

\begin{abstract}
In light of the worldwide spreading requirements related to the disclosure of nonfinancial information, which are aligning to the Sustainable Development Goals (SDGs) developed by the United Nations (UN) in 2015, the study aims to analyse the influence of sustainability and other non-financial reporting on companies' engagement in earnings management practices, through a pre-post adoption of European Directive 2014/95/EU comparative analysis for firms listed on the Bucharest Stock Exchange (BSE) in the period 2015-2019. To conduct the investigation, the research involves the assessment and analysis of three earnings management metrics resulted by running multiple linear regression models on a sample of 31 companies listed on BSE. Research findings emphasise a decrease in the use of income smoothing practices by sampled companies in the post-adoption period 2017-2019, compared to the period preceding the implementation of the EU directive related to mandatory disclosure of non-financial information, 20152016. Thus, firms characterised by a higher transparency in terms of sustainability reporting are less inclined to engage in earnings management practices. This research complements the literature in the field of sustainability reporting and earnings management, providing empirical evidence on the significance and impact of publishing non-financial information.
\end{abstract}

Keywords: sustainability reporting; earnings management; European Directive 2014/95/EU; nonfinancial reporting; sustainable development goals (SDGs); empirical research

\section{Introduction}

Investigating the relationship between non-financial reporting and earnings management is motivated by three theories, according to Gerged et al. [1], namely the stakeholders' theory, the agency theory, and the legitimacy theory. Based on the stakeholders' theory, companies' management will avoid engaging in earnings management practices and will adopt an environmentally responsible image to achieve their stakeholder's expectations. In terms of the agency theory, the information asymmetry provides the opportunities for managers to serve their personal interest, which might trigger some negative consequences. Thus, managers will be inclined to compensate these actions by increasing the quality and quantity of non-financial information disclosure. Lastly, based on the legitimacy theory, companies' engagement in sustainability practices might be associated to reporting a better financial performance, as a strategy to improve stakeholders' perception on the companies' image [1].

Previous research on the association between the disclosure of non-financial information and earnings management revealed mixed or even contrasting results. On the one hand, some studies found evidence of a negative relationship between sustainability disclosure and earnings manipulation [1-2], suggesting that companies exhibiting a by higher level of sustainability engagement are less inclined to apply earnings management techniques [2], and as well as implying that the environmentally responsible managers are less likely to be engaged in earnings management practices in [1]. 
On the other hand, there are studies that found a positive association between sustainability practices and earnings management, highlighting that companies with better corporate social responsibility (CSR) performance are more likely to engage in earnings management practices through the increase of discretionary accruals [3]. This relationship might be explained by the fact that managers engage in earnings management either because of the high costs of conducting environmental activities, or as a means to mask their opportunistic behaviour by disclosing more non-financial information [4].

The study aims to investigate the influence of sustainability and other non-financial reporting on companies' engagement in earnings management practices, through a prepost adoption of European Directive 2014/95/EU comparative analysis for firms listed on the Bucharest Stock Exchange (BSE) in the period 2015-2019. The approach is also connected to the implementation of the UN's sustainable development goals issued in 2015, and in particular to SDG 12 Responsible consumption and production, with target 12.6 referring to encouraging companies, especially large and transnational companies, to adopt sustainable practices and to integrate sustainability information into their reporting cycle. The indicator used for measuring the achievement of this target is the number of companies publishing sustainability reports [2,5].

To conduct the investigation, the research involves the assessment of three earnings management metrics resulted by running multiple linear regression models developed based on previous studies [6-7], on a sample of 31 companies listed on BSE.

The research results reveal that the adoption of the European Directive 2014/95/EU related to mandatory presentation of non-financial information led to a decrease in the use of earnings management practices by companies listed on the Bucharest Stock Exchange in the post-EUD period, 2017-2019, in comparison to the pre-EUD period, 20152016. These findings are based on empirical evidence of firms exhibiting less income smoothing in the post-adoption period, after validating two out of three tested hypotheses, and they are in line with previous studies showing a negative association between non-financial reporting and earnings management [2], including in emerging economies $[1,8]$.

This study extends the research field by showcasing an emerging economy and fills the gap of prior research that focused on other contexts or provided inconclusive results $[2,9]$. Concerning the research contribution, the results are noteworthy from several points of view and relevant for various stakeholders, especially for investors in terms of an increase in usefulness for the decision-making process, as well as state authorities and standard setters in assessing the impact of the new regulations. Moreover, this research complements the literature in the field of sustainability reporting and earnings management, providing empirical evidence on the significance and relevance of disclosing non-financial information.

The remainder of this paper is structured as follows. The next section reviews the relevant literature investigating the relationship between non-financial reporting and earnings management, highlighting the background of the study. This is followed by the research methodology presenting the data, metrics and empirical design applied in the analysis. The fourth section emphasises and discussed the findings of the study, then the paper concludes with the ending remarks, research limitations and developments for future research on the impact of sustainability reporting.

\section{Literature Review and Research Hypotheses}

\subsection{Current Context on Sustainable Development and Non-Financial Reporting}

There are several reporting frameworks that companies can apply to disclose nonfinancial information and sustainability issues, the most spread ones that are implemented at an international level being the following [10-13]:

- Global Reporting Initiative (GRI);

- $\quad$ The $<\mathrm{IR}>$ framework of the International Integrated Reporting Council (IIRC); 
- United Nations Global Compact (UNGC);

- The Sustainability Accounting Standards Board (SASB) framework.

In 2015, all United Nations member states adopted the 2030 Agenda for sustainable development, a global action program aimed at developing and promoting the balance between the three dimensions of sustainable development, namely the economic, social, and environmental [14]. The sustainable development goals (SDGs), that are standing at the centre of the 2030 Agenda, outline the necessary actions to be taken in order to eradicate poverty, combat inequalities and protect the planet by 2030 [15]. Prior studies revealed that companies are employing different approaches to identify and report on their contributions to the SDGs, as well as to identify opportunities to align their business strategies with the SDGs [16].

European Directive 2014/95/EU (EUD) is the first step taken in the direction of requiring corporates to provide mandatory non-financial information [17]. The regulation, enforced starting with reporting year 2017, refers to sustainability disclosure, such as environmental, social, and employee information, human rights, and anti-corruption and bribery matters, and the disclosure of diversity policies for board members [17-18]. According to previous research conducted by Manes-Rossi et al. [19], European companies exhibit a high level of compliance with the EUD provisions and their corresponding guidelines.

\subsection{Overview on Earnings Management Phenomenon}

Healy and Wahlen [20] provide one of the most cited definitions of earnings management, stating that earnings management occurs when managers use their professional judgment in financial reporting and the classification of transactions aiming to alter the financial statements with the purpose of misleading current and potential investors with respect to the firm's economic performance, or to influence contractual outcomes conditioned by achieving a certain level of the financial indicators.

Dechow and Skinner [21] analyse the concept of earnings management starting with the role of accruals, as there are forms of earnings' manipulation that are difficult to distinguish from appropriate practices inherent to accrual accounting. Supporting the same perspective, Stolowy and Breton [22] emphasise that earnings management consists in the means of dealing with differences between the application of accrual accounting and cash accounting.

There are various empirical metrics that can be used to assess earnings management engagement, a classification of those models is emphasised by prior literature [2324]:

- models based on the analysis of accruals and their correlation with cash flows, examining the level of earnings management as a determinant of the quality of financial information;

- models based on value relevance of accounting information, analysing the correlation between firms' market value and equity book value;

- models that examine specific factors that exert an influence on financial reporting;

- models based on the qualitative characteristics of information, analysing the quality of financial reporting in terms of its usefulness in making economic decisions.

The first two categories of models are applied for the assessment of firms' earnings quality focusing on earnings management, which is considered as having a negative influence on the quality of financial reporting, particularly with respect to usefulness in the decision-making process [23].

The financial reporting framework is a significant factor that influences the quality of accounting information. Previous studies highlighted an improvement in accounting quality after the adoption of the International Financial Reporting Standards, showing that companies that are applying this framework exhibit less earnings manipulation practices [6]. In this context, the mandatory implementation of the IFRS also determined 
an increase in the volume of environmental information reported by companies, as a consequence of applying the provisions of those standards related to the disclosure of environmental aspects [11]. Moreover, by corroborating the IFRS with the Global Reporting Initiative (GRI), the quality of reporting increases, as companies that adopted the GRI have recorded both an increase of their financial performance, as well as their market value, compared to firms that did not apply the environmental framework $[11,25]$.

\subsection{Particularities of the Romanian Setting}

The focus of this research on the Romanian environment is motivated by several factors. Firstly, most of the previous studies investigating the relationship between corporate social responsibility (CSR) and earnings management (EM) have examined either companies operating in common law countries, or in Asian countries, and with reference to the European setting, in Spain and Germany [2]. Similar to prior literature based on single-country studies, such as the ones dealing with the Italian context $[2,17,26]$, this study analyses the particular case of Romania, a civil law country that is characterised by a relatively small number of public interest entities.

In addition, academic literature indicates that emerging markets are to some extent neglected, arguing that there is a necessity for this gap to be addressed [8]. Other research findings referring to developed countries cannot be extrapolated to developing contexts, considering that stakeholders in these settings affect differently the decisionmaking process related to release of non-financial reports [9].

Secondly, starting with reporting year 2017, the provisions of Directive 2014/95/EU, which refers to the presentation of non-financial information, are transposed in the national legislation through the M.P.F. Orders no. 1938/2016 and no. 2844/2016. According to the new regulations, public interest entities that exceed at the balance sheet date the criterion of having an average number of 500 employees during the financial year include in the administrators' report a non-financial statement containing information on at least environmental, social and personnel aspects, respect for human rights, fight against corruption and bribery, to the extent that these issues are necessary to understand the development, the performance and position of the entity, as well as the impact of its activity [10,27]. In this context, previous studies highlighted that the EU directive adoption had a positive impact on the level of transparency in case of Romanian listed companies [28], as well as an increase in value relevance in terms of the influence exerted on the market value of capital as a result of reporting on sustainability issues [10].

Moreover, sustainable development is a constituent of the Romanian public policy and national strategy, as well as a subject of academia and civil society attention [10]. According to the database of voluntary national reports available on the Sustainable Development Knowledge Platform [29], Romania is one of the UN state members that joined the Sustainable Development Goals initiative of the 2030 Agenda, and volunteered to provide national reports on the state of the SDGs achievement, the first and only reporting year to date being 2018 [14]. The interest and engagement in sustainable development is also emphasised by the launch of the first initiative focused on reporting ESG indicators for the Romanian capital market [30].

In terms of the applicable accounting regulations, throughout the entire examined period companies listed on the Bucharest Stock Exchange prepared their financial statements in accordance with the International Financial Reporting Standards (IFRS). Therefore, similar to the prior studies [31], the obtained results are not impacted by changes of the accounting framework.

To investigate the relationship between sustainability reporting and earnings management, assessing whether the disclosure of non-financial information by companies listed on BSE after the adoption of the EU directive leads to a decrease in the use of earnings manipulation techniques, the following research hypotheses were considered and tested: 
H1: The variability of net income is higher in the post-EUD period, 2017-2019, compared to the pre-EUD period, 2015-2016, indicating a decrease of income smoothing for companies listed on BSE.

$\mathrm{H} 2$ : The ratio of the variability of net income to the variability of operating cash flows is higher in the post-EUD period, 2017-2019, compared to the pre-EUD period, 2015-2016, suggesting a decrease of income smoothing for companies listed on BSE.

H3: There is a greater correlation between accruals and cash flows in the post-EUD period, 2017-2019, compared to the pre-EUD period, 2015-2016, as evidence that firms engage less in income smoothing practices after the EU directive adoption.

The methodology employed to validate the three hypotheses is presented in the next section of the study.

\section{Materials and Methods}

Following previous research on the impact of non-financial reporting [2,10,31-32], the study aims to determine the extent to which disclosing non-financial information on sustainable development by companies listed on the Bucharest Stock Exchange leads to a decrease of the engagement in earnings management practices. Hereinafter, the research methodology presents the selection criteria of the analysed sample, as well as the procedures applied for collecting the data, continuing with the definition and measurement of the variables and the construction of the empirical models.

\subsection{Data Collection and Sample Description}

In light of the efforts and measures taken at the national level towards aligning to sustainability principles and achieving the SDGs, the research aims to analyse whether the disclosure of non-financial information related to sustainable development by companies listed on the Bucharest Stock Exchange influences the use of earnings management practices. To conduct the investigation, data necessary for the measurement of variables used in the study that are based on financial-accounting indicators presented in the companies' individual financial statements were collected from the S\&P Capital IQ database [33]. Therefore, at the date the research was conducted (February-May 2021), out of the 79 companies trading their shares on BSE's regulated market in the Premium and Standard tiers, 48 companies were eliminated as a consequence of applying the selection criteria presented in Table 1.

Table 1. Sample selection criteria.

\begin{tabular}{ccc}
\hline Analysed criteria & $\begin{array}{c}\text { Number of } \\
\text { companies }\end{array}$ & $\begin{array}{c}\text { Number of firm- } \\
\text { year observations }\end{array}$ \\
\hline $\begin{array}{c}\text { Excluded financial institutions } \\
\text { ulated market }\end{array}$ & 79 & 395 \\
liquidation & -8 & -40 \\
Excluded firms with suspended activity or undergoing & -5 & -25 \\
Excluded firms with unavailable data & -27 & -135 \\
Excluded observations with negative equity & -8 & -40 \\
Excluded observations showing outliers & 0 & -2 \\
Final sample & 31 & 153 \\
\hline
\end{tabular}

Similar to previous research $[2,10,32,34]$, financial companies such as banks and non-banking financial institutions were eliminated from the sample, considering them being a subject to specific regulations and differing in terms of their financial position structure. Firms having their shares suspended from trading or undergoing liquidation were also excluded from the analysis, as well as those firms that were missing the neces- 
sary financial or non-financial information in the period 2015-2019. According to similar studies [31], the observations that disclosed negative book values of equity were also eliminated from the sample. As a last step, after applying the statistical tests meant to check the robustness of the econometric models, 2 observations showing a level of the studentized residuals higher than 3 in absolute value were identified as outliers and truncated as a consequence [35].

Following this procedure, the resulting sample comprises a number of 153 firmyear observations associated to 31 companies for the time interval of 2015-2019.

Table 2 emphasises below the entities' breakdown on industries using the Global Industry Classification Standard (GICS), taxonomy that was developed in 1999 by to the MSCI and S\&P Dow Jones Indices [36] and referenced in similar studies [10,35].

Table 2. Industry breakdown of the analysed sample.

\begin{tabular}{ccc}
\hline Industry primary sector & No. of companies & $\begin{array}{c}\text { Percentage of firm- } \\
\text { year observations }\end{array}$ \\
\hline Consumer Discretionary & 5 & $16.34 \%$ \\
Consumer Staples & 1 & $3.27 \%$ \\
Energy & 7 & $22.22 \%$ \\
Health Care & 3 & $9.80 \%$ \\
Industrials & 4 & $13.07 \%$ \\
Information Technology & 1 & $3.27 \%$ \\
Materials & 6 & $18.95 \%$ \\
Real Estate & 1 & $3.27 \%$ \\
Utilities & 3 & $9.80 \%$ \\
\hline Total & 31 & $100.00 \%$ \\
\hline
\end{tabular}

The predominant industry in the sample is represented by the energy sector, that is covering almost a quarter of the analysed observations, followed by the materials sector with $18.95 \%$ and consumer discretionary with $16.34 \%$ of the sample. The least representative industry sectors are the consumer staples, information technology, and real estate equally showing a percentage of $3.27 \%$ of the total firm-year observations.

The collection of data for the measurement of variables related to non-financial reporting issues used in the applied research models was based on the GRI Sustainability Disclosure Database [37], as employed in prior research [32,38]. Given that this database gathers information provided by the companies voluntarily, the collected data was cross-examined with the non-financial reports published on the companies' websites. Thus, for those entities not found in the GRI database, if the sustainability reports or other non-financial reports were available on the firm's website, the necessary information was hand-collected from the reports published by the company [38].

Furthermore, for the assessment of the extent to which corporates referred to the Sustainable Development Goals (SDGs) in the analysed reports, the textual content analysis of the reports was conducted [39-40], by applying search queries for keywords such as "sustainability", "sustainable", "goals", "2030 Agenda".

With respect to the analysed time frame, the period 2015-2019 was included in the investigation, taking into account several aspects as follows:

- $\quad$ in 2015 the sustainable development goals have been proposed by the UN and numerous countries worldwide publicly expressed their adherence to the goals;

- 2017 is the first year for companies to report in accordance with the requirements of the European Directive 2014/95/EU relative to the mandatory disclosure of nonfinancial information;

- 2019 is the most recent year showing published non-financial reports for the BSE listed companies; even though the annual financial reports became available at the 
end of April 2021, as a requirement of the BSE Rulebook [41], the sustainability and other non-financial related reports are published at a later date.

Therefore, the two periods analysed for the pre- vs. post-EUD comparison are 20152016, with 61 firm-year observations for the period preceding the adoption of the European Directive, and 2017-2019 for the period following the implementation of the new non-financial reporting provisions, with 92 firm-year observations.

Moreover, the outcome of applying the following methodology is not influenced by any differences in terms of the accounting framework, as companies listed on the BSE are required to prepare their financial reports according to the International Financial Reporting Standards (IFRS). In addition, companies have the obligation to adhere to the highest governance standards, as defined in the Corporate Governance Code of the Bucharest Stock Exchange, focusing on the provisions related to management responsibilities, risk management and the internal control and fair rewards system [41].

\subsection{Variables Definition and Research Design}

The academic literature is rich in empirical research investigating the relationship between corporate social performance and financial performance, showing a wide range of mixed findings [16]. Nevertheless, there are fewer studies focusing on the influence of non-financial reporting on earnings management practices, seen as a proxy of financial reporting quality. Some of these studies found a negative relationship between nonfinancial information disclosure and the use of earnings manipulation techniques [1-2,8], while others discovered a positive relationship [3-4,42-43]. However, given the variety of motives to engage in corporate social responsibility activities [9], as well as the numerous incentives for manipulating earnings [44], the contradictory results might not be surprising.

In this context, the methodology presented hereafter is applied to determine whether firms listed on the BSE engage less in earnings management practices after the adoption of directive 2014/95/EU related to the mandatory disclosure of non-financial information.

To achieve the research objective, the three proposed hypotheses are tested based on the following earnings management metrics, obtained by adapting the models engaged by previous studies [6-7,23]. All variables included in the regression models are defined in Table 3.

For the first hypothesis (H1), the analysed earnings smoothing metric relies on the variability of the change in net income scaled by total assets $(\Delta \mathrm{NI})$, interpreting a smaller variance of this metric as evidence of income smoothing. To control for factors that are not attributable to changes related to non-financial reporting legislation and that might be impacting companies' net income, the variability of this metric is measured as the variance of the residuals, $\Delta \mathrm{NI}^{*}$, from the regression given by eq. (1) [6-7,23]:

$$
\begin{aligned}
\Delta \mathrm{NI}_{\mathrm{it}}=\alpha_{0}+\alpha_{1} \mathrm{GRIREP}_{\mathrm{it}}+ & \alpha_{2} \mathrm{SDG}_{\mathrm{it}}+\alpha_{3} \mathrm{SIZE}_{\mathrm{it}}+\alpha_{4} \mathrm{GROWTH}_{\mathrm{it}}+\alpha_{5} \mathrm{EISSUE}_{\mathrm{it}}+\alpha_{6} \mathrm{LEV}_{\mathrm{kit}}+\alpha_{7} \mathrm{DISSUE}_{\mathrm{it}}+ \\
& \alpha_{8} \mathrm{TURN}_{\mathrm{it}}+\alpha_{9} \mathrm{CF}_{\mathrm{it}}+\alpha_{10} \mathrm{IND}_{\mathrm{kit}}+\alpha_{11} \text { YEAR }_{\mathrm{kit}}+\varepsilon_{\mathrm{it}},
\end{aligned}
$$

To validate the second hypothesis (H2), the next income smoothing metric is based on the assumption that firms with more volatile cash flows should exhibit more volatile net income. Hence, if companies use accruals to manipulate earnings, the variability of the change in net income should be lower than that of operating cash flows. In this context, the second analysed metric is computed as the mean ratio of the variability of the change in net income, $\Delta \mathrm{NI}^{*}$, to the variability of the change in operating cash flows, $\Delta \mathrm{CF}^{*}$. Similar to the previous judgement applied for eq. (1), to control for factors not related to the non-financial reporting legislation, $\triangle \mathrm{CF}^{*}$ is the variance of the residuals obtained from the regression shown by eq. (2), with $\triangle \mathrm{CF}$ as the dependent variable [6$7,23]$ : 


$$
\begin{aligned}
\Delta \mathrm{CF}_{\mathrm{it}}=\alpha_{0}+\alpha_{1} \mathrm{GRIREP}_{\mathrm{it}}+ & \alpha_{2} \mathrm{SDG}_{\mathrm{it}}+\alpha_{3} \mathrm{SIZE}_{\mathrm{it}}+\alpha_{4} \mathrm{GROWTH}_{\mathrm{it}}+\alpha_{5} \mathrm{EISSUE}_{\mathrm{it}}+\alpha_{6} \mathrm{LEV}_{\mathrm{kit}}+\alpha_{7} \mathrm{DISSUE}_{\mathrm{it}}+ \\
& \alpha_{8} \mathrm{TURN}_{\mathrm{it}}+\alpha_{9} \mathrm{CF}_{\mathrm{it}}+\alpha_{10} \mathrm{IND}_{\mathrm{kit}}+\alpha_{11} \mathrm{YEAR}_{\mathrm{kit}}+\varepsilon_{\mathrm{it}},
\end{aligned}
$$

For the third and last of the hypotheses considered, the earnings management metric is based on the Spearman correlation between accruals and cash flows. To this end, as with the previous two metrics, the correlation of residuals $\left(\mathrm{CF}^{*}\right.$ and $\left.\mathrm{ACC}^{*}\right)$ resulted from the regression models given by equations (3) and (4) is analysed, rather than the correlation between CF and ACC directly. Accruals are determined as the difference between net income and cash flows. Both dependent variables (CF and ACC) are regressed on the same variables as in eq. (1) and eq. (2), but excluding CF [6-7,23]:

$$
\begin{aligned}
& \mathrm{CF}_{i t}=\alpha_{0}+\alpha_{1} \mathrm{GRIREP}_{\mathrm{it}}+\alpha_{2} \mathrm{SDG}_{\mathrm{it}}+\alpha_{3} \mathrm{SIZE}_{\mathrm{it}}+\alpha_{4} \mathrm{GROWTH}_{\mathrm{it}}+\alpha_{5} \mathrm{EISSUE}_{\mathrm{it}}+\alpha_{6} \mathrm{LEV}_{\mathrm{kit}}+\alpha_{7} \mathrm{DISSUE}_{\mathrm{it}}+ \\
& \alpha_{8} \mathrm{TURN}_{\mathrm{it}}+\alpha_{9} \mathrm{IND}_{\mathrm{kit}}+\alpha_{10} \mathrm{YEAR}_{\mathrm{kit}}+\varepsilon_{\mathrm{it}} \\
& \mathrm{ACC}_{\mathrm{it}}=\alpha_{0}+\alpha_{1} \mathrm{GRIREP}_{\mathrm{it}}+\alpha_{2} \mathrm{SDG}_{\mathrm{it}}+\alpha_{3} \mathrm{SIZE}_{\mathrm{it}}+\alpha_{4} \mathrm{GROWTH}_{\mathrm{it}}+\alpha_{5} \mathrm{EISSUE}_{\mathrm{it}}+\alpha_{6} \mathrm{LEV}_{\mathrm{kit}}+\alpha_{7} \mathrm{DISSUE}_{\mathrm{it}}+ \\
& \alpha_{8} \mathrm{TURN}_{\mathrm{it}}+\alpha_{9} \mathrm{IND}_{\mathrm{kit}}+\alpha_{10} \mathrm{YEAR}_{\mathrm{kit}}+\varepsilon_{\mathrm{it}},
\end{aligned}
$$

\begin{tabular}{|c|c|}
\hline Variable & Measurement \\
\hline$\Delta \mathrm{NI}$ & Change in net income scaled by total assets \\
\hline$\triangle \mathrm{CF}$ & Change in operating cash flows scaled by total assets \\
\hline $\mathrm{ACC}$ & Accruals - Net income minus operating cash flows \\
\hline GRIREP & $\begin{array}{l}\text { Dichotomous variable that equals } 1 \text { if company i published a sustainability report in accordance with } \\
\text { GRI standards for financial year } t \text {, and } 0 \text { otherwise }\end{array}$ \\
\hline SDG & $\begin{array}{l}\text { Dichotomous variable that equals } 1 \text { if company i mentioned the SDGs in the sustainability report pub- } \\
\text { lished for financial year } t \text {, and } 0 \text { otherwise }\end{array}$ \\
\hline SIZE & Natural logarithm of total assets \\
\hline GROWTH & Percentage change in sales \\
\hline EISSUE & Percentage change in common shares \\
\hline LEV & Leverage-Total liabilities divided by equity book value \\
\hline DISSUE & Percentage change in total liabilities \\
\hline TURN & Sales divided by end of year total assets \\
\hline $\mathrm{CF}$ & Net cash flow from operating activities divided by end of year total assets \\
\hline LOSS & $\begin{array}{l}\text { Dichotomous variable that equals } 1 \text { if company i obtained a negative net income (loss) for financial year } \\
\qquad \text {, and } 0 \text { otherwise }\end{array}$ \\
\hline IND & $\begin{array}{l}\text { Binary dummy variable for each country (Consumer discretionary omitted, set as reference); the variable } \\
\text { equals } 1 \text { if industry is } k \text { (where } k=1-8 \text {, for each of the industries under GICS classification), and } 0 \text { oth- } \\
\text { erwise }\end{array}$ \\
\hline YEAR & $\begin{array}{l}\text { Binary dummy variable for each year (2015 omitted, set as reference); the variable equals } 1 \text { if the year is } \\
\qquad \mathrm{k} \text { (where } \mathrm{k}=1-4 \text {, for each of the years } 2016,2017,2018 \text { and } 2019) \text {, and } 0 \text { otherwise }\end{array}$ \\
\hline
\end{tabular}

The variables used in equations (1)-(4) are defined and measured as shown in Table 3.

Table 3. List of variables and their measurement.

In addition to the dependent variables described above, building on prior research investigating the influence of non-financial information on firms' financial reporting [10,45-46], and earnings management practices in particular [1-4,43], variables GRIREP and SDG are capturing the non-financial data. GRIREP indicates the extent to which firms publish non-financial reporting prepared according to GRI standards [3,45-46], while SDG highlights whether companies are engaged in achieving the sustainable development goals adopted by the UN, referring to the SDGs in the contents of their nonfinancial reports [10]. The necessary data for the measurement of these variables was collected from the GRI Sustainability Disclosure Database and cross-examined conducting 
a content analysis of the firms' non-financial reports published on their websites [31$32,38]$.

Several control variables are included in the models to mitigate the impact of other factors that might exert an influence on the changes in net income and changes in cash flows. Therefore, following previous studies, the four models are using controls for firms' size (SIZE), expressed as natural logarithm of total assets [1-4,6-7], change in sales (GROWTH) [6-7], change in the number of common shares (EISSUE) [6-7], change in total liabilities (DISSUE) [6-7], leverage determined as liabilities to equity book value ratio (LEV) [1-4,6-7], sales to total assets ratio (TURN) [6-7], net cash flows from operating activities (CF) for models given by eq. (1) and (2) [6-7], and whether companies obtained a loss in the analysed period, measured using a dichotomous variable (LOSS) [2,31].

Dummy binary variables have been included in the regression models to eliminate possible effects of industry (IND) and differences between years (YEAR), this approach being consistent with most research papers applying a similar methodology [31-32,3435].

In order to compile the multiple regression models and to conduct all statistical tests necessary for processing the data, IBM SPSS Statistics 27 was used as software resource.

\section{Empirical Results and Discussion}

The findings of the study are highlighted below in terms of descriptive statistics, correlation coefficients, regression results and interpretation of the earnings management metrics.

\subsection{Descriptive Statistics and Correlation Analysis}

Table 4 provides information related to the mean, median, standard deviation, as well as minimum and maximum values of the sample consisting in 155 firm-year observations for the entire analysed period, 2015-2019.

Table 4. Descriptive statistics of the entire sample, period 2015-2019 ( $\mathrm{N}=155)$.

\begin{tabular}{cccccc}
\hline Variable & Mean & Median & Std. Deviation & Minimum & Maximum \\
\hline$\Delta \mathrm{NI}$ & -3.308 & -0.072 & 42.183 & -524.550 & 9.418 \\
$\Delta \mathrm{CF}$ & 0.708 & -0.087 & 8.645 & -21.186 & 78.440 \\
ACC & -0.022 & -0.029 & 0.071 & -0.267 & 0.360 \\
GRIREP & 0.226 & 0.000 & 0.419 & 0.000 & 1.000 \\
SDG & 0.077 & 0.000 & 0.268 & 0.000 & 1.000 \\
SIZE & 5.017 & 4.553 & 1.592 & 2.660 & 9.203 \\
GROWTH & 0.090 & 0.062 & 0.344 & -0.586 & 3.709 \\
EISSUE & 0.010 & 0.000 & 0.070 & -0.137 & 0.671 \\
LEV & 0.658 & 0.466 & 0.597 & 0.049 & 3.311 \\
DISSUE & 0.128 & 0.034 & 0.459 & -0.457 & 3.917 \\
TURN & 0.688 & 0.627 & 0.381 & 0.119 & 1.911 \\
CF & 0.079 & 0.076 & 0.081 & -0.288 & 0.385 \\
LOSS & 0.116 & 0.000 & 0.321 & 0.000 & 1.000 \\
\hline
\end{tabular}

Based on these statistics, there is no evidence of significant changes in the companies' levels of reported sales (mean value of percentage change in sales, GROWTH, of 0.09 and standard deviation of 0.344 ), or the levels of reported liabilities (mean value of percentage change in liabilities, DISSUE, of 0.128, with a standard deviation of 0.459) throughout the entire analysed time frame, 2015-2019. Furthermore, the sample also shows there were no significant changes in the firms' number of common shares (EIS- 
SUE variable with the smallest mean of 0.01 , and standard deviation of 0.07$)$. Slightly over 10\% of analysed corporates recorded a loss during 2015-2019 (mean value of the variable LOSS being of 0.116) and a little less than a quarter of the firms published nonfinancial reports in accordance with the GRI standards (mean of 0.226 for the GRIREP binary variable) over the same period. In addition, amongst these companies, only a third part of them also disclosed information related to their engagement in achieving the UN's sustainable development goals (mean of 0.077 for the dichotomous variable SDG).

Additional data related to the mean and standard deviations of the two remaining subsamples (pre-EUD period, 2015-2016, of 61 firm-year observations and post-EUD period, 2017-2019, of 92 firm-year observations), after applying the necessary procedures to eliminate the resulted outliers, is provided in Appendix A, Table A1.

Comparing the statistics of the two subsamples, Table A1 indicates an improvement in terms of the disclosure of non-financial information in accordance with GRI standards after the adoption of the EU directive 2014/95/EU, with a mean value of 0.304 for the GRIREP variable in the post-EUD period, compared to the mean of 0.115 for the preEUD period. A similar positive influence is observed with respect to the presentation of information referring to the SDGs (mean of 0.109 in the post-EUD period, compared to the mean of 0.033 in the pre-EUD period for variable SDG). Also, there are fewer firms recording a loss in the post-EUD period, between 2017 and 2019, as compared to the period before the implementation of the EU directive for non-financial reporting (mean of 0.109 in the post-EUD period, compared to the mean of 0.033 in the pre-EUD period for variable SDG). Moreover, no significant differences in means between the pre- vs. postEUD intervals are found for the changes in sales (GROWTH), the firms' leverage ratio (LEV), the sales to total assets ratio (TURN), or the reported cash flows from operating activities (CF).

For determining the bivariate associations between the variables included in the regression models, as well as to assess the multicollinearity assumption, the Pearson correlation analysis was conducted as disclosed in Table 5.

Table 5. Pearson correlation matrix.

\begin{tabular}{|c|c|c|c|c|c|c|c|c|c|c|c|c|}
\hline Variable & $\Delta \mathrm{NI}$ & $\Delta \mathrm{CF}$ & ACC & GRIREP & SDG & SIZE & GROWTH & EISSUE & LEV & DISSUE & TURN & $\mathrm{CF}$ \\
\hline$\Delta \mathrm{NI}$ & 1.000 & & & & & & & & & & & \\
\hline$\Delta \mathrm{CF}$ & 0.005 & 1.000 & & & & & & & & & & \\
\hline $\mathrm{ACC}$ & 0.032 & $-0.202^{* * *}$ & 1.000 & & & & & & & & & \\
\hline GRIREP & 0.041 & -0.009 & $-0.260^{* * * * *}$ & 1.000 & & & & & & & & \\
\hline SDG & 0.022 & -0.022 & -0.150 & $0.536^{* * * *}$ & 1.000 & & & & & & & \\
\hline SIZE & -0.062 & -0.051 & $-0.256^{* * * *}$ & $0.489^{* * *}$ & $0.378^{* * *}$ & 1.000 & & & & & & \\
\hline GROWTH & 0.054 & -0.035 & 0.112 & -0.112 & 0.030 & -0.071 & 1.000 & & & & & \\
\hline EISSUE & 0.004 & -0.108 & 0.101 & -0.066 & -0.027 & -0.015 & 0.016 & 1.000 & & & & \\
\hline LEV & -0.129 & 0.031 & 0.048 & $0.188^{* *}$ & 0.119 & 0.077 & -0.012 & -0.003 & 1.000 & & & \\
\hline DISSUE & 0.023 & -0.025 & $0.146^{*}$ & -0.103 & -0.056 & -0.089 & 0.086 & -0.061 & 0.060 & 1.000 & & \\
\hline TURN & -0.072 & $0.236^{* * *}$ & -0.046 & 0.076 & 0.082 & -0.091 & -0.035 & -0.037 & $0.589^{* * *}$ & -0.117 & 1.000 & \\
\hline $\mathrm{CF}$ & 0.006 & $0.212^{* * * *}$ & $-0.696^{* * * *}$ & 0.112 & 0.075 & $0.235^{* * * *}$ & -0.049 & -0.089 & $-0.174^{* *}$ & -0.086 & 0.059 & 1.000 \\
\hline LOSS & 0.022 & -0.022 & $-0.207^{* * * *}$ & 0.093 & 0.121 & -0.050 & 0.074 & -0.051 & $0.238^{* * *}$ & -0.091 & $0.175^{* *}$ & $-0.214^{* * * *}$ \\
\hline
\end{tabular}

${ }^{* * *}$ Correlation is significant at the 0.01 level (2-tailed); ${ }^{* *}$ Correlation is significant at the 0.05 level (2-tailed); ${ }^{*}$ Correlation is significant at the 0.1 level (2-tailed).

In addition to the Pearson correlation coefficients that are analysed to identity any multicollinearity issues in accordance with most of previous studies [1-2,4,31], the 
Spearman's rho coefficients are also disclosed in Table 6, for a more relevant interpretation of the associations involving binary variables (GRIREP, SDG, LOSS) $[1,7,10]$.

Table 6. Spearman's rho correlation matrix.

\begin{tabular}{|c|c|c|c|c|c|c|c|c|c|c|c|c|}
\hline Variable & $\Delta \mathrm{NI}$ & $\Delta \mathrm{CF}$ & ACC & GRIREP & SDG & SIZE & GROWTH & EISSUE & LEV & DISSUE & TURN & CF \\
\hline$\Delta \mathrm{NI}$ & 1.000 & & & & & & & & & & & \\
\hline$\Delta \mathrm{CF}$ & $0.241^{* * *}$ & 1.000 & & & & & & & & & & \\
\hline ACC & -0.022 & $-0.461^{* * *}$ & 1.000 & & & & & & & & & \\
\hline GRIREP & -0.091 & $0.177^{* *}$ & $-0.319^{* * *}$ & 1.000 & & & & & & & & \\
\hline SDG & -0.093 & 0.035 & $-0.219^{* * *}$ & $0.536^{* * *}$ & 1.000 & & & & & & & \\
\hline SIZE & -0.040 & 0.102 & $-0.301^{* * *}$ & $0.397^{* * *}$ & $0.232^{* * *}$ & 1.000 & & & & & & \\
\hline GROWTH & $0.278^{* * *}$ & -0.015 & $0.158^{* *}$ & -0.122 & 0.081 & $-0.143^{*}$ & 1.000 & & & & & \\
\hline EISSUE & -0.091 & 0.059 & 0.023 & 0.098 & 0.052 & 0.020 & -0.112 & 1.000 & & & & \\
\hline LEV & -0.124 & -0.070 & 0.023 & 0.092 & 0.057 & 0.008 & 0.108 & -0.031 & 1.000 & & & \\
\hline DISSUE & -0.061 & -0.028 & $0.172^{* *}$ & -0.047 & -0.016 & 0.018 & 0.099 & -0.039 & 0.035 & 1.000 & & \\
\hline TURN & -0.082 & -0.075 & 0.021 & 0.051 & -0.009 & $-0.135^{*}$ & 0.059 & -0.046 & $0.638^{* * *}$ & -0.060 & 1.000 & \\
\hline $\mathrm{CF}$ & $0.287^{* * *}$ & $0.457^{* * *}$ & $-0.598^{* * *}$ & 0.118 & 0.127 & $0.218^{* * *}$ & 0.043 & -0.003 & -0.113 & -0.092 & 0.052 & 1.000 \\
\hline LOSS & $-0.223^{* * *}$ & 0.043 & $-0.225^{* * *}$ & 0.093 & 0.121 & -0.101 & $-0.208^{* * *}$ & -0.013 & $0.211^{* * *}$ & -0.063 & $0.153^{*}$ & $-0.278^{* * *}$ \\
\hline
\end{tabular}

${ }^{* * *}$ Correlation is significant at the 0.01 level (2-tailed); ${ }^{* *}$ Correlation is significant at the 0.05 level (2-tailed); ${ }^{*}$ Correlation is significant at the 0.1 level (2-tailed).

Considering the coefficients in both tables, it can be concluded that the sampled data presents no evidence of any multicollinearity issues, as the correlation coefficients between all independent variables are below the conventional threshold of $0.7[10,32,38]$.

Furthermore, both Pearson and Spearman's rho coefficients indicate a positive above average association between firms leverage (LEV) and sales over total assets ratio (TURN), significant at the $1 \%$ level, as well as positive correlations between changes in sales (GROWTH) and changes in net income $(\Delta \mathrm{NI})$, also significant at the $1 \%$ level, revealing as expected that an increase in sales will lead to an increase in net income. Significant positive associations are also found between the level of operating cash flows $(\mathrm{CF})$ and changes in net income $(\triangle \mathrm{NI})$, respectively changes in net cash flows $(\triangle \mathrm{CF})$. As expected, negative correlations are shown by the Pearson coefficient of -0.696 between accruals (ACC) and cash flows (CF), as well as the one between SIZE and ACC of -0.256, both being statistically significant at the $1 \%$ level. These findings are similar to the ones obtained by Lang et al. [7].

With respect to the dichotomous variables, taking into account the results based on the Spearman's rho coefficients, the strongest positive correlation is found between GRIREP and SDG, with a significant medium correlation coefficient of 0.536 at the $1 \%$ level, highlighting that, as expected, companies that are reporting based on the GRI standards are more likely to be engaged in achieving the UN SDGs. There is also a positive, although weaker, correlation between the disclosure of non-financial information related to SDGs and firm size, shown by the correlation coefficient of 0.232 between SDG and SIZE variables, significant at the $1 \%$ level. Moreover, the negative association between the ACC and SDG variables, of -0.219 significant at the $1 \%$ level, emphasises that companies exhibiting greater levels of accruals are less inclined to disclose non-financial information related to the sustainable development goals.

Another binary variable referring to the disclosure of information on ESG aspects is GRIREP, showing significant positive associations at the $1 \%$ level with firms' size (SIZE, Spearman's rho coefficient of 0.397 ) and at the $5 \%$ level with the change in cash flows $(\triangle \mathrm{CF}$, Spearman's rho coefficient of 0.177$)$, respectively. On the contrary, a negative correlation with GRIREP is found for the ACC variable (Spearman's rho coefficient of - 
0.319), being significant at the $1 \%$ level, interpreted as evidence that firms reporting greater accrual values are less likely to publish non-financial reports aligned with the GRI standards.

In terms of the effect of reporting a negative financial performance, the binary variable LOSS is analysed, exhibiting a negative correlation with the changes in sales (GROWTH) and the level of accruals (ACC), both significant at the 1\% level. In addition, there is a significant positive association between LOSS and LEV, also at the $1 \%$ level, emphasising that firms confronted with negative results are showing a higher leverage ratio.

The additional analysis of the tolerance and variance inflation factor (VIF) also indicated that the variables are not affected by multicollinearity, as all coefficients are within the acceptable thresholds, showing tolerance values greater than 0.1 and VIF lower than $10[4,31,35]$. Details in this regard can be found in Appendix B, Table A2.

\subsection{Regression Results}

The results obtained after running the four multiple linear regression models as presented by eq. (1)-(4) on the two subsamples (post-EUD period 2017-2019 and preEUD period 2015-2016) with industry and year fixed effects are disclosed in Table 7. The pre- vs. post-EUD comparative analysis shows the coefficients and models' goodness of fit statistics.

Table 7. Results of the pre- vs. post-EUD comparative analysis for the four multiple linear regression models.

\begin{tabular}{|c|c|c|c|c|c|c|c|c|}
\hline \multirow{3}{*}{$\begin{array}{l}\text { Variable / } \\
\text { Statistics }\end{array}$} & \multicolumn{4}{|c|}{ Post-EUD period 2017-2019 } & \multicolumn{4}{|c|}{ Pre-EUD period 2015-2016 } \\
\hline & $\begin{array}{l}\text { Model 1, } \\
\text { Eq. (1) }\end{array}$ & $\begin{array}{l}\text { Model 2, } \\
\text { Eq. (2) }\end{array}$ & $\begin{array}{c}\text { Model 3, } \\
\text { Eq. (3) }\end{array}$ & $\begin{array}{c}\text { Model 4, } \\
\text { Eq. (4) }\end{array}$ & $\begin{array}{l}\text { Model 1, } \\
\text { Eq. (1) }\end{array}$ & $\begin{array}{l}\text { Model 2, } \\
\text { Eq. (2) }\end{array}$ & $\begin{array}{c}\text { Model 3, } \\
\text { Eq. (3) }\end{array}$ & $\begin{array}{c}\text { Model 4, } \\
\text { Eq. (4) }\end{array}$ \\
\hline & $\Delta \mathrm{NI}$ & $\Delta \mathrm{CF}$ & CF & ACC & $\Delta \mathrm{NI}$ & $\Delta \mathrm{CF}$ & CF & $\mathrm{ACC}$ \\
\hline Intercept & 0.277 & 1.382 & $-0.056^{+}$ & 0.037 & -0.018 & 2.755 & $-0.070^{+}$ & 0.004 \\
\hline GRIREP & 0.101 & $1.347 \dagger$ & 0.004 & -0.017 & -1.086 & -1.911 & -0.022 & -0.050 \\
\hline SDG & 0.587 & -0.041 & -0.007 & -0.006 & 0.089 & 8.416 & -0.013 & 0.006 \\
\hline SIZE & 0.035 & -0.240 & $0.029^{* * *}$ & $-0.016^{* *}$ & -0.260 & -2.412 & $0.020^{*}$ & -0.003 \\
\hline GROWTH & $1.657^{*}$ & $-2.842^{*}$ & -0.018 & 0.050 & $5.113^{* * *}$ & $6.755^{+}$ & 0.020 & -0.014 \\
\hline EISSUE & -2.540 & 2.651 & $-0.259^{* *}$ & 0.111 & $-7.745^{* *}$ & -21.581 & -0.025 & 0.100 \\
\hline LEV & -0.703 & 0.481 & $-0.108^{* * *}$ & $0.062^{* *}$ & -0.393 & -0.396 & $-0.036^{*}$ & 0.015 \\
\hline DISSUE & -0.284 & 0.034 & -0.003 & -0.006 & 0.692 & 0.384 & -0.003 & 0.003 \\
\hline TURN & -0.285 & -1.313 & $0.076^{* *}$ & $-0.036^{+}$ & 0.668 & $9.004+$ & $0.076^{* *}$ & 0.000 \\
\hline CF & -0.064 & $13.728^{* * *}$ & - & - & 0.857 & $47.248^{+}$ & - & - \\
\hline LOSS & -0.731 & 0.559 & 0.004 & $-0.058^{*}$ & -0.660 & 1.191 & -0.010 & $-0.057^{* *}$ \\
\hline Industry FE & Yes & Yes & Yes & Yes & Yes & Yes & Yes & Yes \\
\hline Year FE & Yes & Yes & Yes & Yes & Yes & Yes & Yes & Yes \\
\hline $\mathrm{R}^{2}$ & 0.280 & 0.286 & 0.489 & 0.431 & 0.711 & 0.504 & 0.476 & 0.330 \\
\hline F-stat & $1.382^{+}$ & $1.425^{+}$ & $3.630^{* * *}$ & $2.871^{* * *}$ & $5.316^{* * *}$ & $2.194^{* *}$ & $2.121^{* *}$ & 1.147 \\
\hline $\begin{array}{l}\text { Number of } \\
\text { firms }\end{array}$ & 31 & 31 & 31 & 31 & 31 & 31 & 31 & 31 \\
\hline $\begin{array}{c}\text { Number of } \\
\text { observations }\end{array}$ & 92 & 92 & 92 & 92 & 61 & 61 & 61 & 61 \\
\hline
\end{tabular}

Significance at the level of: ${ }^{* * *} p<0.01 ;{ }^{* *} p<0.05 ;{ }^{*} p<0.10 ;{ }^{+} p<0.20$.

As shown in Table 7, the regression models emphasised by equations (1) and (2), related to the variability of the change in net income, and the variability of the change in cash flows, respectively, are statistically significant at the $1 \%$ level $(\Delta \mathrm{NI})$ and at the $5 \%$ 
level $(\triangle \mathrm{CF})$ for the EU directive pre-adoption period, and statistically significant at the $20 \%$ level for the post-adoption time frame (both $\Delta \mathrm{NI}$ and $\Delta \mathrm{CF}$ ). With respect to equations (3) and (4), the regression models are significant at the $1 \%$ level for the post-EUD period (both for CF and ACC dependent variables) and at the 5\% level for the pre-EUD period (only for dependent variable CF).

The findings related to the regression coefficients reveal that firm size (SIZE) positively influences cash flows from operating activities (CF), with significance at the level of $1 \%$, considering the coefficient of 0.029 in the post-EUD period, as well as the coefficient of 0.020 at the $10 \%$ level for the pre-EUD period, with an increase of this influence both in value and significance after the implementation of directive 2014/95/EU.

As opposed to firm size, the leverage ratio ( $\mathrm{LEV}$, determined as total debt to equity book value) exerts a negative impact on cash flows from operating activities (CF), statistically significant at the $1 \%$ level in the post-EUD period, and at the $5 \%$ level for the preEUD period.

In respect of the three hypotheses tested in the study, the main statistically significant research findings obtained after the application of the regression models on the sample of 31 BSE listed companies on the regulated market, consisting of 92 firm-year observations for the post-EUD period and 61 firm-year observations for the pre-EUD period, are summarised in Table 8.

Table 8. Summary of results based on the pre- vs. post-EUD comparison of the earnings management metrics obtained after applying the four regression models for testing the three proposed hypotheses.

\begin{tabular}{cccccc}
\hline Earnings management metric & Hypothesis & Prediction & $\begin{array}{c}\text { Post-EUD period } \\
\text { 2017-2019 (N = 92) }\end{array}$ & $\begin{array}{c}\text { Pre-EUD period } \\
\text { 2015-2016 (N = 61) }\end{array}$ & Validated \\
\hline Variability of $\Delta \mathrm{NI}^{*}$ & $\mathrm{H} 1$ & Post $>$ Pre & $1.048^{+}$ & $1.101^{* * *}$ & No \\
Variability of $\Delta \mathrm{NI}^{*}$ over $\Delta \mathrm{CF}^{*}$ & $\mathrm{H} 2$ & Post $>$ Pre & $0.961^{+}$ & $0.882^{* *}$ & Yes \\
Correlation of $\mathrm{ACC}^{*}$ and $\mathrm{CF}^{*}$ & $\mathrm{H} 3$ & Post $>$ Pre & $-0.771^{* * *}$ & $-0.796^{* * *}$ & Yes \\
\hline
\end{tabular}

Significance at the level of: ${ }^{* * *} p<0.01 ;{ }^{* *} p<0.05 ;{ }^{+} p<0.20$.

The research employed three measures of earnings management, each corresponding to one of the three proposed hypotheses. As presented in Table 8, findings reveal that two of the three tested hypotheses are validated after applying the regression models described by equations (1)-(4), that led to the measurement of the analysed earnings management metrics.

For the first hypothesis (H1), the only one that was not validated, it was assumed that the variability of net income is higher in the post-EUD period, 2017-2019, compared to the pre-EUD period, 2015-2016, interpreting the result as evidence of a decrease in the use of income smoothing techniques for companies listed on BSE. On the contrary, results show a slight reduction of the variability of changes in net income from 1.101 (significant at the $1 \%$ level) for the period prior to the adoption of the EU directive, compared to the value of 1.048 (significant at the 20\% level) obtained for the same metric in the post-EUD period. Although this hypothesis was not confirmed, the result should be interpreted with caution and corroborated with those found for the other assumptions, especially considering the decrease in the statistical significance of the metric in the postEUD period.

The second hypothesis (H2) was based on the ratio of the variability of net income to the variability of operating cash flows, assuming this metric will show a higher value in the post-EUD period, 2017-2019, compared to the pre-EUD period, 2015-2016, as evidence of a decrease in the use of earnings smoothing for companies listed on BSE. As expected, according to the results disclosed in Table 8, the second analysed metric computed as the mean ratio of the variability of the change in net income, $\Delta \mathrm{NI}^{*}$ (determined as variance of residuals of the regression model in eq. (1)), to the variability of the 
change in operating cash flows, $\triangle \mathrm{CF}^{*}$ (determined as variance of residuals of the regression model in eq. (2)) recorded an increase in the post-EUD period (0.961 for 2017-2019), compared to the pre-EUD period (0.882 for 2015-2016). This is interpreted as evidence of a decrease in terms of earnings manipulation practices used by the sampled companies listed on the BSE regulated market after the adoption of the EU directive related to mandatory non-financial reporting. The result is based on the assumption that firms with more volatile cash flows should exhibit more volatile net income. Hence, if companies use accruals to manipulate earnings, the variability of the change in net income should be lower than that of operating cash flows. These findings are statistically significant at the 5\% level for the pre-EUD period and at the $20 \%$ level for the post-EUD period, respectively.

The third and last hypothesis (H3) was based on the prediction that there is a greater correlation between accruals and cash flows in the post-EUD period, 2017-2019, compared to the pre-EUD period, 2015-2016, suggesting that firms engage less in income smoothing practices after the EU directive adoption. The earnings management metric presented for H3 in Table 8 is the Spearman correlation between accruals and cash flows, measured as the Spearman's rho coefficient between the residuals ( $\mathrm{CF}^{*}$ and $\mathrm{ACC}^{*}$ ) resulted from the regression models given by equations (3) and (4), rather than the correlation between CF and ACC directly. Consistent with the previous metric, the third result indicates that the correlation between accruals $\left(\mathrm{ACC}^{*}\right)$ and cash flows $\left(\mathrm{CF}^{*}\right)$ for the post-EUD period (of -0.771 , at the $1 \%$ level) is significantly less negative than for the preEUD period (of -0.796 , at the $1 \%$ level). These findings emphasise that the analysed BSE listed companies are smoothing earnings less after the implementation of the EU directive 2014/95 related to the disclosure of non-financial reporting starting with 2017.

Thus overall, considering the above mentioned results, having two out of three validated hypotheses, it can be concluded that the adoption of the European Directive 2014/95/EU related to mandatory presentation of non-financial information led to a decrease in the use of earnings management practices by companies listed on the Bucharest Stock Exchange in the post-EUD period, 2017-2019, based on empirical evidence of exhibiting less income smoothing, in comparison to the pre-EUD period, 2015-2016. These findings are consistent with prior studies showing a negative association between nonfinancial reporting and earnings management [2], including in emerging economies $[1,8]$.

To verify the statistical robustness of the regression models used in the research, several procedures were applied to assess whether the criteria related to the normal distribution of residual values, multicollinearity, and dealing with outliers are met. The test results showed that all assumptions were verified and all statistical criteria were met to allow the use of the four multiple linear regression models.

\section{Conclusions and Limitations}

The disclosure of non-financial information is increasingly spreading worldwide, hence the analysis of its impact is becoming the subject of more and more studies from several perspectives. This research was conducted with the objective of determining to what extent the adoption of the European Directive 2014/95/EU related to the mandatory disclosure of non-financial information in Romania starting with reporting year 2017 positively influenced the use of earnings management practices by companies listed on the regulated market of the Bucharest Stock Exchange.

To investigate the association between non-financial reporting and earnings management and achieve the research objective, three earnings management metrics were built and analysed in correlation to the three proposed hypotheses, after applying four multiple linear regression models as employed by similar studies [6-7].

The research results reveal that the adoption of the European Directive 2014/95/EU related to mandatory presentation of non-financial information led to a decrease in the use of earnings management practices by companies listed on the Bucharest Stock Ex- 
change in the post-EUD period, 2017-2019, in comparison to the pre-EUD period, 20152016. These findings are based on empirical evidence of firms exhibiting less income smoothing in the post-adoption period, after validating two out of three tested hypotheses, and they are in line with previous studies showing a negative association between non-financial reporting and earnings management [2], including in emerging economies $[1,8]$.

This study extends the research field by showcasing an emerging economy and fills the gap of prior research that focused on other contexts or provided inconclusive results $[2,9]$. Concerning the research contribution, the results are noteworthy from several points of view and relevant for various stakeholders, especially for investors in terms of an increase in usefulness for the decision-making process, as well as state authorities and standard setters in assessing the impact of the new regulations. Moreover, this research complements the literature in the field of sustainability reporting and earnings management, providing empirical evidence on the significance and relevance of disclosing non-financial information.

The main limitation of the research refers to the relatively reduced sample selected for analysis, that is usually a characteristic of studies that are conducted on a singlecountry level, especially in the case of emerging economies [10-11]. Similar to Grimaldi [2], the limited sample was also a consequence of data unavailability with respect to ESG scores for companies listed on the BSE. Another implication of this aspect was the necessity of hand-collecting ESG related data from firms' reports, which might raise issues regarding the subjectivity of textual or content analysis as a research method.

Future research directions could regard extending the sample by including companies with similar characteristics from other countries, as well as applying other regression models suitable to this type of analysis, also adding variables based on ESG international indices such as MSCI ESG Index or S\&P Dow Jones ESG Index.

Funding: This research received no external funding.

Data Availability Statement: The data presented in this study are available on request from the corresponding author.

Conflicts of Interest: The author declares no conflict of interest.

\section{Appendix A}

Table A1. Descriptive statistics of the final subsamples (without outliers), pre-post EUD comparison.

\begin{tabular}{|c|c|c|c|c|}
\hline \multirow[t]{2}{*}{ Variable } & \multicolumn{2}{|c|}{$\begin{array}{l}\text { Post-EUD period 2017-2019 } \\
\qquad(\mathrm{N}=92)\end{array}$} & \multicolumn{2}{|c|}{$\begin{array}{l}\text { Pre-EUD period 2015-2016 } \\
(\mathrm{N}=61)\end{array}$} \\
\hline & Mean & Std. Deviation & Mean & Std. Deviation \\
\hline$\Delta \mathrm{NI}$ & 0.136 & 1.458 & -0.132 & 2.335 \\
\hline$\Delta \mathrm{CF}$ & -0.096 & 2.510 & 1.922 & 13.408 \\
\hline $\mathrm{ACC}$ & -0.010 & 0.077 & -0.039 & 0.059 \\
\hline GRIREP & 0.304 & 0.463 & 0.115 & 0.321 \\
\hline SDG & 0.109 & 0.313 & 0.033 & 0.180 \\
\hline SIZE & 5.068 & 1.576 & 4.926 & 1.643 \\
\hline GROWTH & 0.087 & 0.191 & 0.096 & 0.498 \\
\hline EISSUE & 0.008 & 0.071 & 0.013 & 0.070 \\
\hline LEV & 0.659 & 0.566 & 0.647 & 0.642 \\
\hline DISSUE & 0.168 & 0.514 & 0.067 & 0.364 \\
\hline TURN & 0.697 & 0.378 & 0.675 & 0.389 \\
\hline CF & 0.073 & 0.088 & 0.088 & 0.072 \\
\hline
\end{tabular}




\begin{tabular}{lllll} 
LOSS & 0.109 & 0.313 & 0.131 & 0.340 \\
\hline
\end{tabular}

\section{Appendix B}

To test the assumption that the sampled data shows no multicollinearity issues, the tolerance and VIF indicators are analysed, as presented in Table A2 [47].

Table A2. Tolerance and variance inflation factors (VIF) statistics of the four regression models.

\begin{tabular}{ccccccccc}
\hline \multirow{2}{*}{ Variable / } & \multicolumn{3}{c}{ Post-EUD period 2017-2019 } & \multicolumn{3}{c}{ Pre-EUD period 2015-2016 } \\
\cline { 2 - 8 } Statistics & \multicolumn{1}{c}{ Models 1-2, Eq. (1)-(2) } & Models 3-4, Eq. (3)-(4) & Models 1-2, Eq. (1)-(2) & Models 3-4, Eq. (3)-(4) \\
\cline { 2 - 8 } & Tolerance & VIF & Tolerance & VIF & Tolerance & VIF & Tolerance & VIF \\
\hline GRIREP & 0.433 & 2.308 & 0.433 & 2.308 & 0.339 & 2.947 & 0.341 & 2.929 \\
SDG & 0.456 & 2.193 & 0.456 & 2.192 & 0.376 & 2.661 & 0.376 & 2.659 \\
SIZE & 0.291 & 3.435 & 0.344 & 2.909 & 0.170 & 5.871 & 0.183 & 5.478 \\
GROWTH & 0.793 & 1.261 & 0.795 & 1.258 & 0.381 & 2.623 & 0.387 & 2.586 \\
EISSUE & 0.781 & 1.281 & 0.836 & 1.196 & 0.736 & 1.360 & 0.736 & 1.358 \\
LEV & 0.203 & 4.921 & 0.252 & 3.962 & 0.400 & 2.500 & 0.435 & 2.300 \\
DISSUE & 0.790 & 1.265 & 0.791 & 1.264 & 0.804 & 1.244 & 0.804 & 1.244 \\
TURN & 0.415 & 2.408 & 0.455 & 2.197 & 0.409 & 2.448 & 0.471 & 2.125 \\
CF & 0.511 & 1.958 & - & - & 0.524 & 1.909 & - & - \\
LOSS & 0.555 & 1.802 & 0.555 & 1.801 & 0.627 & 1.596 & 0.628 & 1.592 \\
\hline
\end{tabular}

As shown in Table A2, the tolerance and VIF statistical indicators for all the variables included in all four regression models are within the normal thresholds, being safe to conclude that the data reflects no multicollinearity issues (tolerance is greater than 0.1 and VIF is smaller than 10) $[4,16,31,35]$.

\section{References}

1. Gerged, A.M.; Al-Haddad, L.M.; Al-Hajri, M. Is earnings management associated with corporate environmental disclosure? Evidence from Kuwaiti listed firms. Accounting Research Journal 2020, 33, 167-185. https://doi.org/10.1108/ARJ-05-2018-0082

2. Grimaldi, F.; Caragnano, A.; Zito, M.; Mariani, M. Sustainability Engagement and Earnings Management: The Italian Context. Sustainability 2020, 12, 4881. https://doi.org/10.3390/su12124881

3. Jordaan, L.A.; De Klerk, M.; De Villiers, C.J. Corporate social responsibility and earnings management of South African companies, South African Journal of Economic and Management Sciences 2018, 21(1), a1849. https://doi.org/10.4102/sajems.v21i1.1849

4. Gargouri, R.M.; Shabou, R.; Francoeur, C. The relationship between corporate social performance and earnings management. Canadian Journal of Administrative Sciences 2010, 27(4), 320-334. https://doi.org/10.1002/cjas.178

5. United Nations Sustainable Development Goal 12. Available online: https://sdgs.un.org/goals/goal12 (accessed on 25 May 2021).

6. Barth, M.; Landsman, W.; Lang, M. International accounting standards and accounting quality. Journal of Accounting Research 2008, 46(3), 467-498. https://doi.org/10.1111/j.1475-679X.2008.00287.x

7. Lang, M.; Raedy, J.; Wilson, W. Earnings management and cross listing: Are reconciled earnings comparable to US earnings? Journal of Accounting and Economics 2006, 42, 255-283. https://doi.org/10.1016/j.jacceco.2006.04.005

8. Yoon, B.; Kim, B.; Lee, J.H. Is Earnings Quality Associated with Corporate Social Responsibility? Evidence from the Korean Market. Sustainability 2019, 11, 4116. https://doi.org/10.3390/su11154116

9. Duran, I.J.; Rodrigo, P. Why Do Firms in Emerging Markets Report? A Stakeholder Theory Approach to Study the Determinants of Non-Financial Disclosure in Latin America. Sustainability 2018, 10, 3111. https://doi.org/10.3390/su10093111

10. Nechita, E. The Value Relevance of Non-Financial Reporting in Determining the Market Value of Equity. Audit Financiar 2021, 162, 320-336. http://dx/doi.org/10.20869/AUDITF/2021/162/009

11. Istrate, C.; Robu, I.B.; Pavaloaia Betianu, L.; Herghiligiu, I. Analysis of companies sustainability under the influence of environmental information disclosure. Environmental Engineering and Management Journal 2017, 16, 957-967. https://doi.org/10.30638/eemj.2017.097

12. Dima, Ș.M.; Popa, A.S.; Farcane, N. Financial and Non-Financial Information in the Framework of Sustainability and Integrated Reporting, Audit Financiar 2015, 122, 21-33. 
13. Albu, N.; Albu, C.N.; Dumitru, M.; Dumitru, V.F. Plurality or convergence in sustainability reporting standards? Amfiteatru Economic 2013, 15(7), 513-527.

14. Nechita, E. Analysis of the Relationship between Accounting and Sustainable Development. The Role of Accounting and Accounting Profession on Sustainable Development, Audit Financiar 2019, 155, 520-536. http://dx/doi.org/10.20869/AUDITF/2019/155/XXX

15. United Nations. Transforming our world: the 2030 Agenda for Sustainable Development. Available online: https://sustainabledevelopment.un.org/content/documents/21252030\%20Agenda\%20for\%20Sustainable\%20Development $\% 20$ web.pdf (accessed on 24 May 2021).

16. Nechita, E.; Manea, C.L.; Nichita, E.-M.; Irimescu, A.-M.; Manea, D. Is Financial Information Influencing the Reporting on SDGs? Empirical Evidence from Central and Eastern European Chemical Companies. Sustainability 2020, $12,9251$. https://doi.org/10.3390/su12219251

17. Carini, C.; Rocca, L.; Veneziani, M.; Teodori, C. Ex-Ante Impact Assessment of Sustainability Information-The Directive 2014/95. Sustainability 2018, 10, 560. https://doi.org/10.3390/su10020560

18. EU Commission. Directive 2014/95/EU of the European Parliament and the Council of 22 October 2014 amending Directive 2013/34/EU as Regards Disclosure of Non-Financial and Diversity Information by Certain large Undertakings and Groups; EU Commission: Brussels, Belgium, 2014; pp. 1-9. Available online: https://eur-lex.europa.eu/legalcontent/RO/TXT/PDF/?uri=CELEX:32014L0095\&from=EN (accessed 31 May 2021).

19. Manes-Rossi, F.; Tiron-Tudor, A.; Nicolò, G.; Zanellato, G. Ensuring More Sustainable Reporting in Europe Using NonFinancial Disclosure-De Facto and De Jure Evidence. Sustainability 2018, 10, 1162. https://doi.org/10.3390/su10041162

20. Healy, P.; Wahlen, J. A review of the earnings management literature and its implication for standard setting. Accounting Horizons 1999, 13, 365-383.

21. Dechow, P.; Skinner, D.J. Earnings management: Reconciling the views of accounting academics, practitioners, and regulators. Accounting Horizons 2000, 14, 235-250.

22. Stolowy, H.; Breton, G. A framework for the classification of accounts manipulations. HEC Research Papers Series 2000, 708, HEC Paris. Available online: http://www.hec.fr/var/fre/storage/original/application/456c089c66d9579417b29c15bbbdc9f6.pdf (accessed 25 May 2021).

23. Nechita, E. Earnings management analysis after IFRS adoption: Evidence from Bucharest Stock Exchange listed companies. Proceedings of the 9th International Conference Accounting and Management Information Systems (AMIS), Bucharest, Romania, 11-12 June 2014; Publisher: Editura ASE, Bucharest, Romania, 2014; 674-690.

24. van Beest, F.; Braam, G.; Boelens, S. Quality of Financial Reporting: measuring qualitative characteristics. Nijmegen Center for Economics (NiCE) Working paper 2009, 8-109. Available online: http://www.ru.nl/publish/pages/516298/nice 09108.pdf (accessed 31 May 2021).

25. Buys P.W; Van Rooyen S.; Bosman P. Do socially conscious companies provide better financial performance? An exploratory study, Studia Universitatis Babes-Bolyai Oeconomica 2009, 54, 3-15.

26. Venturelli, A.; Caputo, F.; Cosma, S.; Leopizzi, R.; Pizzi, S. Directive 2014/95/EU: Are Italian Companies Already Compliant? Sustainability 2017, 9, 1385. https://doi.org/10.3390/su9081385

27. Order of the Ministry of Public Finance no. 1938/2016 of August, 17 2016, related to the amendment of accounting regulations. Available online: https://static.anaf.ro/static/10/Anaf/legislatie/OMFP_1938_2016.pdf (accessed 20 May 2021).

28. Tiron-Tudor, A.; Nistor, C.S.; Ştefănescu, C.A.; Zanellatto, G. Encompassing Non-Financial Reporting in A Coercive Framework for Enhancing Social Responsibility: Romanian Listed Companies' Case. Amfiteatru Economic 2019, 21(52), 590-606. DOI: $10.24818 / \mathrm{EA} / 2019 / 52 / 590$

29. Sustainable Development Knowledge Platform. Voluntary National Reviews Database. Available online: https://sustainabledevelopment.un.org/vnrs/ (accessed 25 May 2021).

30. Bucharest Stock Exchange. Press release - Bucharest Stock Exchange Launches the First ESG-Focused Initiative on the Romanian Capital Market. Available online: https://www.bvb.ro/press/2020/Press\%20release ESG EN.pdf (accesed February 2021).

31. Baboukardos, D.; Rimmel, G. Value relevance of accounting information under an integrated reporting approach: a research note. Journal of Accounting and Public Policy 2016, 35(4), 437-452. https://doi.org/10.1016/j.jaccpubpol.2016.04.004

32. Grassmann, M. The relationship between corporate social responsibility expenditures and firm value: The moderating role of integrated reporting. Journal of Cleaner Production 2021, 285, 124840. https://doi.org/10.1016/j.jclepro.2020.124840

33. Compustat Database. S\&P Capital IQ Platform. Available online: https://www.capitaliq.com/CIQDotNet/Analytics.aspx? (accessed 15 March 2021).

34. Tlili, M.; Othman, H.B.; Hussainey, K. Does integrated reporting enhance the value relevance of organizational capital? Evidence from the South African context. Journal of Intellectual Capital. 2019, 20(5), 642-661. https://doi.org/10.1108/JIC-02-20190034

35. Hassel, L.; Nilsson, H.; Nyquist, S. The value relevance of environmental performance. The European Accounting Review 2005, 14(1), 41-61.

36. MSCI. The Global Industry Classification Standard (GICS®). Available online: https://www.msci.com/gics (accessed 15 March 2021).

37. Global Reporting Initiative. GRI Sustainability Disclosure Database. Available online: https://database.globalreporting.org/search/ (accessed 20 March 2021). 
38. Landau, A.; Rochell, J.; Klein, C.; Zwergel, B. Integrated reporting of environmental, social, and governance and financial data: does the market value integrated reports?. Business Strategy and the Environment 2020, 29(4), 1750-1763. https://doi.org/10.1002/bse.2467

39. Li, F. Textual Analysis of Corporate Disclosures: A survey of Literature. Journal of Accounting Literature 2020, $29,143-165$.

40. Hummel, K. Reporting on the Sustainable Development Goals-Early Evidence from Europe. Available online: https://ssrn.com/abstract=3411017 (accessed 10 April 2021). http://dx.doi.org/10.2139/ssrn.3411017

41. Bucharest Stock Exchange. Bucharest Stock Exchange Rulebook 2019 . Available online: https://www.bvb.ro/Juridic/files/EN_\%20Rulebook\%20RMO\%20_21102019_site.pdf (accessed 20 May 2021).

42. Brahmana, R.K.; Tan, M.Y.; You, H.W. Corporate environmental disclosure and earning management. Int. J. Green Economics 2018, 12, 308-321. DOI: 10.1504/IJGE.2018.10019190

43. Kuo, Y.F.; Lin, Y.M.; Chien, H.F. Corporate social responsibility, enterprise risk management, and real earnings management: Evidence from managerial confidence. Finance Research Letters 2020, 101805, https://doi.org/10.1016/j.frl.2020.101805

44. Nechita, E. Some Issues on Earnings Management and the Quality of Financial Reporting for Listed Companies. Audit Financiar 2013, 104, 34-43.

45. Kuzey, C.; Uyar, A. Determinants of sustainability reporting and its impact on firm value: evidence from the emerging market of Turkey. Journal of Cleaner Production 2017, 143, 27-39.

46. de Klerk, M.; de Villiers, C. The value relevance of corporate responsibility reporting: South African evidence. Meditari Accountancy Research 2012, 20(1), 21-38. DOI:10.1108/10222521211234200

47. Huber, P.J. Robust Statistics; John Wiley \& Sons: New York, NY, USA, 1981. 